\title{
Peningkatan Kemampuan Berwirausaha Pembuatan Bubuk Kopi Bagi Ikatan Pemuda Desa Cubadak Air dan Sikapak Barat Kecamatan Pariaman Utara, Kota Pariaman
}

\author{
Arwizet Karudin $\left.{ }^{*}\right)$, Zainal Abadi², dan Sri Rizki Putri Primandari ${ }^{3}$ \\ ${ }^{1}$ Pendidikan Teknik Mesin, Teknik Mesin, Fakultas Teknik, Universitas Negeri Padang \\ ${ }^{2}$ Diploma Teknik Mesin, Teknik Mesin, Fakultas Teknik, Universitas Negeri Padang \\ ${ }^{3}$ Teknik Mesin, Teknik Mesin, Fakultas Teknik, Universitas Negeri Padang \\ *)Corresponding author, $\equiv$ arwizet@ft.unp.ac.id
}

Artikel Histori:

Diterima 12/06/2020;

Revisi 23/07/2020;

Publish 28/08/2020
Kata kunci:

usia produktif kopi, roasting kopi, grinding kopi, packing kopi, bubuk kopi

\begin{abstract}
Abstrak
Artikel ini bertujuan untuk menganalisis proses pelatihan dalam rangkan peningkatan kemampuan berwirausaha pembuatan bubuk kopi bagi ikatan pemuda di desa Cubadak Air dan Sikapak Barat. Metode pelatihan yang digunakan adalah metode ceramah dan demonstrasi. Pelatihan ini diikuti oleh 10 orang peserta yang berasal dari Desa Cubadak Air dan Sikapak Barat. Metode ceramah berupa penyampaian teori tentang kopi, teknik rosting, teknik grinding, packing dan pemasaran kopi. Metode demonstrasi digunakan mulai dari cara meroasting, menggrinding dan packing kopi. Hasil pelatihan terlihat bahwa peserta sangat termotivasi dan serius mengikuti pelatihan hal terlihat dari skor tes yang diberikan telah terjadi peningkatan yang signifikan pengetahuan dan keterampilan peserta tentang kopi, teknik roasting, grinding dan packing kopi dari rata-rata skor 63,0 menjadi 84,2. Dapat disimpulkan bahwa peserta mampu menyerap dengan baik pengetahuan dan keterampilan yang diberikan selama pelatihan. Diharapkan akan muncul wirausaha-wirausaha baru dalam bidang pembuatan bubuk kopi di daerah ini.
\end{abstract}

\section{PENDAHULUAN}

\section{Analisis Situasi}

Kota Pariaman merupakan salah satu kota di Sumatera Barat yang tahun 2009 dilanda oleh gempa bumi yang hebat. Hampir 90\% infrastruktur ekonomi dan sosialnya hancur. Dua desa dari banyak desa yang porak poranda akibat gempa bumi tersebut adalah desa Cubadak Air dan Sikapak Barat. Meskipun saat ini kedua desa tersebut roda perekonomiannya sudah mulai bangkit kembali, namun sisa-sisa dari dampak gempa tersebut hingga kini masih dapat dirasakan. Belum semua masyarakat mampu membangun rumahnya seperti dulu lagi, masih banyak masyarakat tinggal di rumah terbuat dari kayu beratapkan seng bekas ala kadarnya. 


\section{Suluah Bendang: Jurnal Ilmiah Pengabdian Kepada Masyarakat}

Vol.20, No.3, 2020

Arwizet Karudin, Sri Rizki Putri Primandari, Zainal Abadi

Masih ada keluarga yang belum mampu menyekolahkan anaknya ke jenjang yang lebih tinggi karena bapaknya yang tidak bekerja, masih banyak pemuda usia produktif yang belum mendapat pekerjaan alias pengangguran. Hal ini disebabkan belum pulihnya infrastruktur perekonomian yang rusak akibat gempa pada tahun 2009 seperti sedia kala.

Berdasarkan survey yang tim pengabdian lakukan serta data dari buku propil desa Cubabak Air dan Sikapak Barat terlihat bahwa 80\% masyarakatnya berusia produktif, 30\% diantaranya masih belum bekerja. Banyaknya pemuda usia produktif ini yang tidak bekerja tentu akan menimbulkan keresahan di masyarakat. Pemuda pengangguran ini tentu akan sangat rentan terseret ke dalam tindakan kriminal seperti pencurian, perampokan dan narkoba. Saat ini kedua desa tersebut di atas masuk dalam wilyah kecamatan yang tingkat kriminal narkobanya nomor dua di Kota Pariaman. Kalau kondisi ini dibiarkan berlarut-larut akan jadi apa para pemudanya pada masa yang akan datang.

Melihat kondisi di atas, maka tim pengabdian melakukan diskusi dan konsultasi dengan kelompok pemuda, beberapa tokoh masyarakat dan kepala desa dari kedua desa ini. Hasil diskusi dan konsultasi maka disepakati bahwa kelompok pemuda dari desa Cubadak Air dan Desa Sikapak Barat akan dijadikan kalayak sasaran dari program pengabdian kepada masyarakat Universitas Negeri Padang dalam skema Program Kemitraan Masyarakat (PKM) pada tahun 2020.

Program pengabdian ini bertujuan untuk meningkatkan kemampuan berwirausaha dalam bidang pembuatan bubuk kopi. Program pengabdian ini merupakan hilirisasi dari hasil penelitian yang sudah pengabdi lakukan sejak tahun 2018. Penelitian yang pengabdi lakukan adalah berkaitan dengan karakteristik berbagai macam kopi khususnya kopi Sumatera Barat, merancang bangun mesin roasting kopi, teknik roasting kopi, teknik grinding kopi dan packing kopi.

Khalayak sasaran pada program pengabdian ini adalah masyarakat yang belum produktif secara ekonomi, tetapi berhasrat kuat menjadi wirausahawan baru dibidang pembuatan bubuk kopi yakni kelompok pemuda yang berasal dari ikatan pemuda Desa Cubadak Air dan Desa Sikapak Barat, Kecamatan Pariaman Utara Kota Pariaman.

Mitra pertama dari program PKM ini adalah kelompok pemuda yang terdiri 8 orang yang dipimpin oleh Bapak Jasman. Bapak Jasman saat ini berusia lebih kurang 36 tahun, sudah berkeluarga dengan dua orang anak. Bapak Jasman pada dasarnya dulu adalah seorang yang berprofesi sebagai penjual pakaian di Kota Bandung, namun nasibnya yang masih belum beruntung maka jualan beliau tidak maju-maju. Oleh karena terbentur biaya hidup dan menyekolahkan anaknya maka beliau pulang ke kampong halaman. Kondisi beliau saat ini cukup memprihatinkan, dalam kondisi pengangguran merasa kesulitan dalam membiayai roda rumah tangganya. Kondisi yang sama juga terjadi pada beberapa orang pemuda lainnya di Desa Cubadak Air. Membuka usaha selain modal tidak ada, keterampilan yang memadai untuk membuka usaha juga tidak punya. Melihat kondisi itu dan didorong oleh permintaan dari Kepala Desa Cubadak Air, maka mendorong tim pengabdian dari UNP memilih kelompok pemuda Desa Cubadak Air yang terdiri dari delapan orang pemuda atau usia produktif menjadi mitra pada program pengabdian ini.

Lokasi kelompok ini beralamatkan pada sebuah rumah milik keluarga dari Bapak Jasman yang cukup luas dan bisa dijadikan sebagai tempat usaha memproduksi bubuk kopi. Tempat ini layak dan nyaman untuk dijadikan tempat pelatihan yang berjarak sekitar $65 \mathrm{~km}$ dari kota Padang.

Mitra kedua dari program PKM ini adalah kelompok pemuda yang berasala dari kelompok pemuda Desa Sikapak Barat. Kondisi sosial ekonomi dari kelompok ini, tim pengabdi rasakan adalah hampir sama dengan kelompok pemuda pada mitra pertama. Kelompok pemuda dari Desa Sikapak Barat ini terdiri dari 6 orang pemuda usia produktif yang di pimpin oleh Bapak

Peningkatan Kemampuan Berwirausaha Pembuatan Bubuk Kopi Bagi Ikatan Pemuda..| 130 Available online: http://sulben.ppj.unp.ac.id 
Budi Utamo. Bapak Budi Utomo berusia sekitar 34 tahun juga sudah bekeluarga dengan 1 orang anak. Saudara Budi Utomo sebelumnya berprofesi sebagai guru honor pada sebuah Sekolah Dasar dan mendapat gaji/upah dibawah upah minimum. Gajinya jelas tidak cukup untuk memenuhi kebutuhan istrin dan anaknya. Untuk menutupi kebutuhannya beliau sorenya beralih menjadi tukang ojek dadakan di desa ini. Hasil menjadi tukang ojek jua tidak menentu dan tidak bisa diharapkan. Beliau menyampaikan kepada ketua tim pengabdi agar dapat kiranya memberikan pelatihan apa saja yang dapat menjadi bekal membuka usaha baginya dan beberapa orang pemuda lainnya di desa ini. Dari kondisi ini maka kami tim pengabdi berdiskusi dan berkonsultasi dengan tokoh masyarakat dan kepala desa Sikapak Barat, maka kelompok ini kami jadikan mitra kedua pada program pengabdian ini. Jarak Desa Sikapak Barat dengan Desa Cubadak Air hanya sekitar $1 \mathrm{~km}$, artinya desa ini berjarak dari kota Padang sekitar $66 \mathrm{~km}$.

Beberapa aspek yang mendorong tim pengabdi memilih bentuk pelatihan pembuatan bubuk kopi adalah: 1) mesin roasting kopi sudah ada hasil hilirisasi penelitian pada tahun 2018; 2) masyarakat daerah ini gemar mengkonsumsi kopi; 3) mudah didapatkannya bahan baku berupa biji kopi mentah (green coffee beans); 4) bubuk kopi hasil roasting juga bisa dipasarkan ke berbagai daerah hingga ke macam negara seperti ke Pekanbaru, Batam dan sebagainya karena bubuk kopi tidak cepat basi.

\section{Solusi dan Target \\ Solusi Permasalahan}

Solusi permasalahan yang ditawarkan kepada mitra didasarkan atas analisis kebutuhan mitra yang diperoleh dari hasil diskusi antara tim pengabdi dengan mitra. Solusi ini bersifat Bottom Up untuk menjawab permasalahan dan kebutuhan prioritas dari mitra. Secara teknis solusi permasalahan yang ditawarkan kepada mitra pada program pengabdian ini dibedakan atas dua aspek yaitu: a) aspek produksi meliputi pengadaan alat-alat atau mesin produksi dan pelatihan peningkatan kemampuan pembuatan bubuk kopi bagi kedua mitra, dan b) aspek manajemen. Secara rinci solusi permasalahan yang ditawarkan kepada kedua mitra adalah: 1) Pengadaan peralatan produksi berupa mesin roasting kopi yang sudah dirancang bangun, 2)Pengadaan mesin grinding biji kopi setelah diroasting dan dijadikan bubuk kopi, 3) Pengadaan alat packing kopi yang dirancang sedemikian rupa untuk mempermudah proses pempackingan kopi yang sudah menjadi bubuk kopi, dan 4) Pelatihan aspek manajemen usaha, keuangan, promosi dan pemasaran produk.

\section{Rencana Kegiatan Pengabdian}

Rencana kegiatan pelatihan peningkatan kemampuan berwirausaha dalam pembuatan bubuk kopi bagi ikatan pemuda desa Cuabdak Air dan Sikapak Barat di rancang dengan langkah-langkah sebagai berikut: a) Mengadakan mesin roasting kopi rotary drier berbahan bakar LPG hasil rancang bangun pada penelitian terdahulu, lalu diperbaiki dan dimodifikasi sedemikian rupa sehingga dapat digunakan dalam pelatihan ini, b) Mengadakan mesin grinding yang berfungsi untuk menggiling kopi dari biji kopi hasil roasting untuk menjadi bubuk kopi siap untuk dikonsumsi, di packing dan dijual, c) Mengadakan mesin atau alat packing sederhana untuk mempermudah proses pembungkusan kopi dengan ukuran 100 gr, 200 gr dan 500 gr. d) Memberikan secara teoritis pengetahuan tentang karakteristik dan jenis-jenis kopi yang ada di Indonesia dan Sumatara Barat khususnya, teknik peroastingan dan packing kopi, e) Demonstrasi praktek peroastingan kopi oleh instruktur. Instruktur memperagakan teknik peroastingan mulai dari pemilihan biji kopi (green coffee beans), pengaturan temperatur dan lama waktu peroastingan, memasukan biji kopi mentah ke dalam mesin roasting, pengontrolan temperatur dan lama waktu roasting, e) Demontrasi proses pendinginan kopi pada sistem pendingin yang ada pada mesin roasting, f) Pelaksanaan praktek uji coba oleh peserta pelatihan 


\section{Suluah Bendang: Jurnal Ilmiah Pengabdian Kepada Masyarakat}

Vol.20, No.3, 2020

Arwizet Karudin, Sri Rizki Putri Primandari, Zainal Abadi

secara berkelompok dibawah pengawasan instruktur pelatihan, g) Proses penggrindingan kopi setelah di roasting menjadi bubuk kopi, h) Proses pempackingan kopi ke dalam packing dalam ukuran 100 gr, 200 gr dan 500 gr, i) Pemberian pengetahuan kepada peserta tentang teknis pengelolaan usaha kopi, administrasi, keuangan dan pemasaran produk kopi.

\section{Prosedur dan Target Kegiatan}

Prosedur kegiatan yang direncanakan dalam Program Kemitraan Masyarakat dalam bentuk pelatihan peningkatan kemampuan berwirausaha dalam pembuatan bubuk kopi bagi kiatan pemuda desa Cubadak Air dan Sikapak Barat ini disusun sebagai berikut: a) Merekrut calon peserta pelatihan dari mitra, b) Melaksanakan kegiatan pelatihan, c) Mengevaluasi kegiatan untuk mendapat masukan guna perbaikan kegiatan serupa pada masa yang akan dating dan melihat apakah kegiatan pelatihan ini sudah sesuai dengan apa yang sudah direncanakan semula. Beberapa kegiatan evaluasi yang dilakukan berupa evaluasi kegiatan secara umum dan mengukur tingat pecapaian pemahaman peserta terhadap meteri yang diberikan dalam pelatihan dalam bentuk posttest diakhir kegiatan pelatihan.

Adapun target dari kegiatan yang dilaksanakan adalah: a) tersedianya mesin roasting kopi, mesin grinding dan packing kopi; b) peserta melakukan praktek perostinga kopi, grinding kopi dan mempacking bubuk kopi; c) membuat variasi rasa beberapa bubuk kopi; d) meningkatnya pengetahuan peserta tentang berbagai karakteristik kopi dan jenis-jenis kopi, teknis peroastingan kopi, teknis penggrindingan kopi dan teknis packing bubuk kopi, pengelolaan usaha bubuk kopi, adminstrasi keuangan dan pemasaran; e) publikasi tentang pelatihan pembuatan bubuk kopi melalui artikel ilmiah, media massa cetak dan media online.

\section{METODE PELAKSANAAN}

Metode pelaksanaan Program Kemitraan Masyarakat Pelatihan Peningkatan Kemampuan Berwirausaha Pembuatan Bubuk Kopi dilakukan melalui tahapan berikut:

\section{Tempat dan Waktu}

Tempat pelaksanaan Program Kemitraan Masyarakat Pelatihan Peningkatan Kemampuan Berwirausaha Pembuatan Bubuk Kopi bagi Ikatan Pemuda Desa Cubadak Air dan Sikapak Barat adalah di Jl. Cndur Mato No. 25 Desa Cubadak Air, Pariaman Utara Kota Pariaman Sumatera Barat dari 6 - 26 Juli 2020.

\section{Khalayak Sasaran}

Pemilihan khalayak sasaran yang dijadikan sebagai mitra diawali oleh observasi, diskusi dan konsultasi dengan pemuda, tokoh masyarakat dan kepala desa yang dilakukan oleh tim pengabdian UNP terhadap beberapa kelompok pemuda di beberapa desa di Kota Pariaman, Sumatera Barat pada 15 sampai 19 Maret 2020. Data yang didapatkan dari hasil observasi, diskusi dan konsultasi dinalisis sedemikian rupa maka dilanjutkan dengan memilih mitra yang berminat dan layak bekerja sama dengan tim pengabdian.

Setelah melalui berbagai pertimbangan, melihat kondisi dan potensi yang bisa di kembangkan maka sasaran pada kegiatan pengabdian skema PKM ini adalah kelompok pemuda di Desa Cubadak Air dan kelompok pemuda di Desa Sikapak Barat. Kelompok Pemuda di Desa Cubadak Air dipimpin oleh Bapak Jasman sedangkan kelompok pemuda di Desa Sikapak Barat di pimpin oleh Bapak Budi Utomo. Kedua mitra berada pada lokasi yang hampir berdekatan dengan jarak lebih kurang $1 \mathrm{~km}$ dan 66 km dari Kota Padang.

\section{Metode Pengabdian}

Metode yang dilakukan dalam pelatihan peningkatan kemampuan berwirausaha pembuatan bubuk kopi bagi ikatan pemuda desa Cubadak Air dan Sikapak Barat adalah sebagai berikut: 
Mengadaan Peralatan Produksi Bubuk Kopi

Peralatan produksi utama dalam pembuatan bubuk kopi yang layak konsumsi dan layak jual kepada masyarakat adalah; mesin roasting biji kopi, mesin grinding biji kopi dan mesin/alat packing buuk kopi ke dalam packingnya dalam ukuran 100 gr, 200 gr dan 500 gr.

Pelatihan Peningkatan Kemampuan Wirausaha Pembuatan Bubuk Kopi

Pelatihan Peningkatan Kemampuan Wirausaha Pembuatan Bubuk Kopi pembuatan bubuk kopi bagi kelompok pemdua ikatan pemuda Desa Cubadak Air dan Sikapak Barat di lakukan melalui tahapan-tahapan berikut: a) Tahap pertama yaitu memberikan pengetahuan secara teroritis kepada peserta materi tentang karakteristik dan jenis-jenis kopi yang ada di Indonesia umumnya dan di Sumatera Barat khususnya, teknis peroastingan kopi, teknis grinding dan packing kopi, b) Tahap kedua yaitu mendemonstrasikan praktek peroastingan kopi oleh instruktur, dimulai dari pemilihan biji kopi (green coffee beans) yang akan diroasting, pengaturan temparatur dan lama waktu peroastingan, kecepatan putar tabung, memasukan biji kopi mnetah ke dalam mesin roasting, dan pendinginan biji setelah diroasting. Peserta memperhatikan dan mencatat langka-langkah yang diperagakan oleh instruktur, c) Tahap ketiga yaitu mendemonstrasikan proses grindingan kopi setelah diroasting dengan mesin grinding kopi sehingga menghasilkan bubuk kopi, d) Tahap keempat yaitu mendemonstrasikan proses packing kopi dengan alat pempacking bubuk kopi, e) Tahap kelima yaitu peserta diagi atas dua kelompok berjumlah 5 orang, lalu peserta mempraktekan proses pembuatan bubuk kopi dimulai dari pemilihan biji kopi mentah (green coffee beans), pengaturan temperatur dan lama peroastingan, putaran tabung mesin roasting, dan pendinginan biji kopi setelah diroasting, f) Tahap keenam yaitu kedua kelompok peserta melakukan penggrindingan biji kopi yang sudah mereka roasting, sehingga dihasilkan bubuk kopi yang siap untuk dikonsumsi, g) Tahap ketujuh yaitu kopi hasil roastingan dari kedua kelompok peserta dinikmati secara bersama selain merasakan cita rasa kopi hasil peroastingan dan pengrindingan kopi, juga membandingkan mana dari kedua kelompok ini kopi hasil pekerjaannya yang sesuai atau mendekati standar kopi yang sudah ada di pasaran, h) Tahap kedelapan yaitu masing-masing kelompok peserta juga ditantang membuat kopi yang diberi bahan tambahan diantaranya adalah: 1) bahan tambahan jagung dengan perbandingan pesentase biji kopi dan jagung adalah 50:50 dan 70:30; 2) bahan tambahan susu kental manis dengan perbandingan 1 kg biji kopi dengan $1 / 2$ kaleng susu kental manis; 3 ) bahan tambahan gula aren asli dengan perbandingan 1 $\mathrm{kg}$ biji kopu dengan $1 / 4 \mathrm{~kg}$ gula aren. Lalu hasilnya dinikmati juga secara bersama mana dari variasi rasa dengan bahan tambahan yang berbeda ini yang paling enak, wangi dan layak konsumsi, i) Tahap kesembilan yaitu proses pengrindingan kopi setelah dirosting dengan berbagai variasi rasa tersebut di atas, j) Tahap kesepuluh yaitu tahap terakhir dimana bubuk kopi hasil grinding di packing dengan baik dengan ukuran 100 gr, 200 gr dan 500 gr. Bubuk kopi yang sudah di packing ini sudah layak untuk dipasarkan ke masyarakat. Pelatihan Bekal Pengetahuan Tentang Bentuk Pengelolaan Usaha, Adminstrasi dan Keuangan, Promosi dan Pemasaran Produk

Peserta diberikan bekal pengetahuan secara teoritik tentang pengelolaan usaha, adminstrasi dan keuangan, promosi dan pemasaran produk oleh instruktur. Pengelolaan usaha diarahkan kepada bagaimana mengelola usaha bubuk kopi. Pengetahuan tentang administrasi dan 


\section{Suluah Bendang: Jurnal Ilmiah Pengabdian Kepada Masyarakat}

Vol.20, No.3, 2020

Arwizet Karudin, Sri Rizki Putri Primandari, Zainal Abadi

keuangan ditujukan agar peserta mampu membuat adminstrasi ushanya dengan baik kelak jika mereka sudah membuka usaha dan mampu membuat neraca keungan yang masuk atau keluar (castflow) usaha mereka dengan baik. Bekal pengetahuan tentang promosi dan pemasaran ditujukan agar peserta memiliki pengetahuan bagaimana cara mempromosikan dan memasarkan produk mereka ke pasar-pasar tradisional maupun secara online.

Setelah pelatihan ini diharapkan kedua kelompok masyarakat ini menjadi kelompok masyarakat yang produktif secara ekonomi selain dapat menghidupi ekonomi keluarga mereka sendiri juga hendaknya mampu membuka lapangan pekerjaan bagi masyarakat lainnya.

Indikator Keberhasilan

Indikator keberhasilan dari program pelatihan ini dikaitkan kesesuaian antara target yang direncanakan dengan hasil yang dicapai dari kegiatan yang sudah direncanakan. Maka indikator keberhasilan pada program kemitraan masyarakat pelatihan peningkatan kemampuan berwirausaha pembuatan bubuk kopi bagi ikatan pemuda desa Cubadak Air dan Sikapak Barat adalah: a) Sudah adanya mesin roasting kopi, mesin grinding dan packing kopi yang bisa digunakan oleh peserta, b) Peserta mampu melakukan praktek perostinga kopi, grinding kopi dan mempacking bubuk kopi, c) Peserta mampu membuat variasi rasa beberapa bubuk kopi, d) Meningkatnya pengetahuan peserta tentang berbagai karakteristik kopi dan jenis-jenis kopi, teknis peroastingan kopi, teknis penggrindingan kopi dan teknis packing bubuk kopi, pengelolaan usaha bubuk kopi, adminstrasi keuangan dan pemasaran, e) Sudah ada publikasi tentang pelatihan pembuatan bubuk kopi dalam bentuk pemberitaan di media cetak dan online, f) Publikasi ilmiah pada jurnal ber ISSN.

\section{Metode Evaluasi}

Evaluasi program bertujuan untuk mengetahui pencapaian tujuan program yang telah dilaksanakan. Selanjutnya hasil evaluasi digunakan sebagai dasar untuk melaksanakan kegiatan tindak lanjut atau untuk melakukan pengambilan keputusan berikutnya. Pada program kemitraan masyarakat (PKM) Pelatihan Peningkatan Kemampuan Berwirausaha Pembuatan Bubuk Kopi ini motode evaluasi yang digunakan adalah metode measurement. Metode ini menitik beratkan kepada hasil yang diperoleh peserta selama proses pelatihan. Untuk itu evaluasi yang dilakukan selain melalui pengamatan, tim juga memberikan test kecil kepada peserta sebelum dan sesudah pelatihan terkait kepada materi tentang jenis-jenis kopi, teknis peroastingan, grinding dan packing serta pemahaman peserta terhadap pengelolaan usaha, keuangan dan pemasaran.

Hasil evaluasi akan dijadikan bahan masukan bagi tim untuk perbaikkan pelaksanaan program pengabdian yang sejenis pada massa yang akan datang. Hasil evaluasi juga akan disampaikan kepada pengambil kebijakkan baik di UNP maupun di daerah, mudah-mudahan akan dijadikan tolok ukur akan pelaksanaan program pengabdian pada massa mendatang.

Keberlanjutan program setelah selesai kegiatan PKM ini dilaksanakan adalah berencana melanjutkan program tersebut ke lain aspek permasalahan yang dialami oleh mitra atau dalam skema program pengabdian kepada masyarakat lainnya.

\section{HASIL DAN PEMBAHASAN}

Hasil yang dicapai pada program pelatihan peningkatan kemampuan berwirausaha bagi ikatan pemuda desa Cubadak Air dan Sikapak Barat, Kecamatan Pariaman Utara, Kota Pariaman Sumatera Barat adalah sebagai berikut:

Peningkatan Kemampuan Berwirausaha Pembuatan Bubuk Kopi Bagi Ikatan Pemuda..| 134 Available online: http://sulben.ppj.unp.ac.id 
Tersedianya Beberapa Alat Produksi pada Pelatihan Peningkatan Kemampuan Berwirausaha Pembuatan Bubuk Kopi

Alat utama produksi pembatan bubuk kopi adalah mesin roasting, mesin grinding dan mesin packing kopi. Sedangkan alat pendukung yang diperluakan berupa baskom dan nampan stainlessteel, pencetus api, kipas angin, timbangan digital, plastic packing dan sebagainya.

Mesin roasting kopi adalah bagian terpenting dari proses pembuatan bubuk kopi. Mesin berfungsi untuk mengubah sifat fisik biji kopi menjadi beraroma, wangi dan bercita rasa. Pada proses peroastingan untuk menentukan apakah kopi diroasting dalam kondisi coklat muda (light brown), coklat tua (dark brown) dan hitam (black).

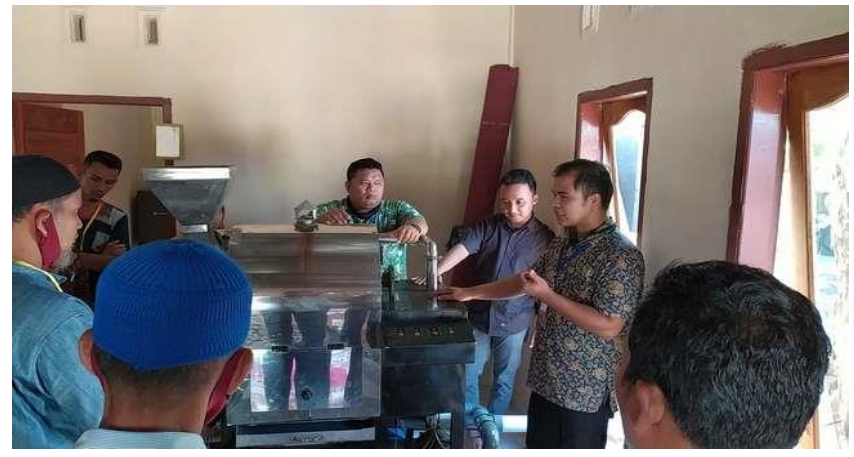

Gambar 1. Mesin roasting kopi berbahan bakar LPG

Selanjutnya yang diadakan juga dalam pelatihan ini adalah mesin grinding biji kopi dan alat packing kopi hasil rancang bangun. Mesin grinding berfungsi untuk menjadikan biji kopi yang sudah di roasting menjadi bubuk kopi. Mesin grinding kopi mempunyai banyak jenis dan kapasitas, namun pada program pelatihan ini mesin grinding kopi yang diadakan mesin grinding berpeggerak motor listrik dengan kapasitas 3-5 kg/jam. Mesin grinding yang diadakan dalam pelatihan adalah mesin grinding kopi seperti terlihat pada gambar 2 .

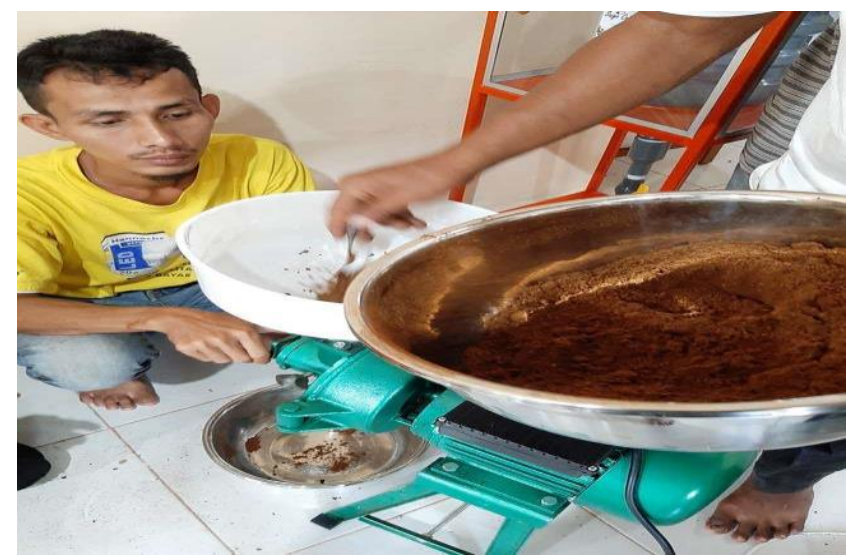

Gambar 2. Mesin grinding kopi sumber penggerak motor listrik dan alat packing bubuk kopi

Alat packing bubuk kopi yang diadakan adalah alat packing bubuk kopi hasil rancang bangun. Alat ini cukup sederhana tetapi sangat membantu saat bubuk kopi dipacking ke dalam ukuran-ukuran tertentu. Alat packing kopi yang digunakan dalam pelatihan ini seperti terlihat pada gambar 3.

Peningkatan Kemampuan Berwirausaha Pembuatan Bubuk Kopi Bagi lkatan Pemuda ..| 135 Available online: http://sulben.ppj.unp.ac.id 


\section{Suluah Bendang: Jurnal Ilmiah Pengabdian Kepada Masyarakat}

Vol.20, No.3, 2020

Arwizet Karudin, Sri Rizki Putri Primandari, Zainal Abadi

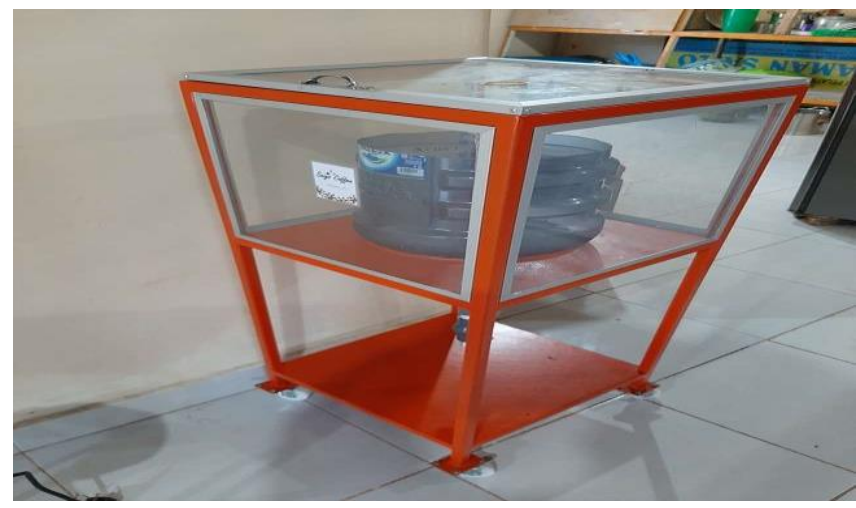

Gambar 3. Alat packing kopi

Selain alat utama di atas, beberapa alat pendukung juga digunakan dalam pelatihan ini diantaranya adalah baskom stainlessteel ukuran sedang dan besar.

Terlaksananya Pelatihan Peningkatan Kemampuan Berwirausaha Pembuatan Bubuk Kopi

Instruktur pada pelatihan peningkatan kemampuan berwirausha pembuatan bubuk kopi khusus untuk teknis peroastingaan kopi adalah Sdr. Ir. Fajri, SP. Beliau adalah seorang praktisi yang bergerak dibidang roasting kopi dan mempunyai bisnis penjualan biji kopi siap roasting dan memiliki kafe kopi dengan merk Kafe Kopi Duo Pintu. Ir. Fajri, SP adalah lulusan dari Fakultas Pertanian, Universitas Andalas.

Teknis pelaksanaan pelatihan pada awalnya instruktur memberikan teori tentang karakteristik dan jenis-jenis kopi, teknis roasting kopi, grinding dan packing kopi. Pemberian teori tentang karakteristik dan jenis-jenis kopi dilakukan dengan metode ceramah. Selama pemberian teori tetang jenis roti dan bahan pembuatan roti, para peserta memperhatikan, mencatat dan bertanya jika ada sesuatu yang kurang dipahami oleh peserta.

Setelah pengetahuan tentang kopi dan teknis roasting, grinding dan packingnya diberikan, maka pelatihan selanjutnya dilakukan praktek pembuatan bubuk kopi. Proses pembuatan bubuk kopi diawali dengan proses peroastingan biji kopi mentah dalam mesin roasting. Proses peroastingan kopi adalah kunci dari bubuk kopi yang dihasilkan apakah beraroma baik, wangi dan bercitarasa. Enak atau tidaknya bubuk kopi yang dihasilkan sangat tergantung pada proses peroastingan ini.

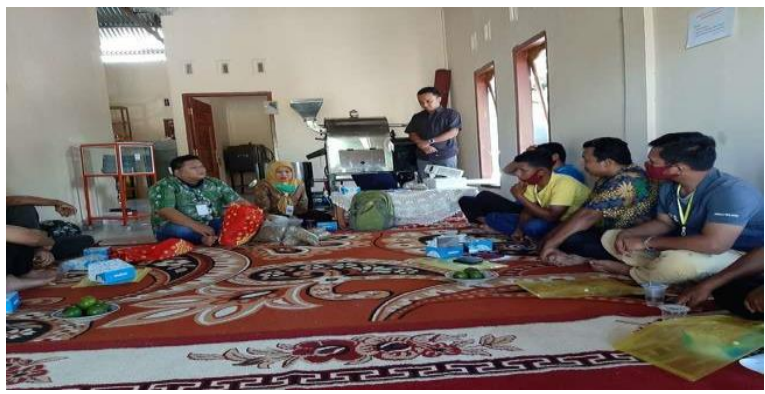

Gambar 4. Pembekalan pengetahuan secara teori tentang kopi, roasting, grinding dan packing kopi

Tahapan proses peroastingan dimulai dari pemilihan biji kopi mentah dalam pelatihan ini setiap peroastingan dilakukan sebanyak $1 \mathrm{~kg}$. Selanjutnya mesin roasting dihidupkan dan api dinyalakan hingga temperatur dalam tabung roasting mencapai $200^{\circ} \mathrm{C}$.

Peningkatan Kemampuan Berwirausaha Pembuatan Bubuk Kopi Bagi Ikatan Pemuda..| 136 Available online: http://sulben.ppj.unp.ac.id 


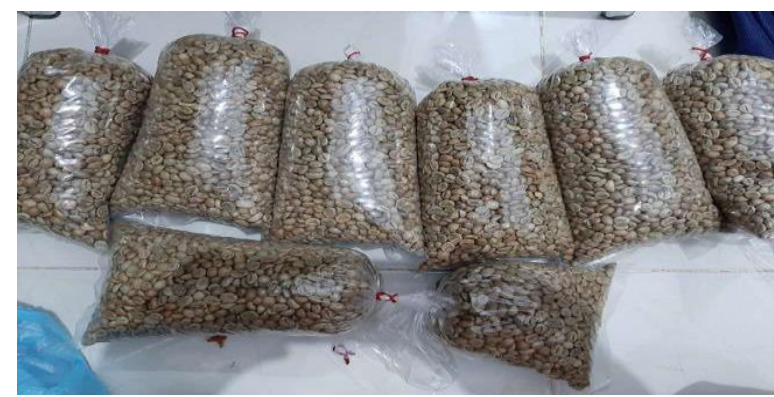

Gambar 5. Pemilihan biji kopi mentah sebelum diroasting

Setelah temperatur tabung menunjukkan angka $200^{\circ} \mathrm{C}$, maka biji kopi siap untuk dimasukkan. Lalu biarkan proses roasting lebih kurang 20 menit sambil mengawasi temperatur tetap konstan dan warna biji kopi menjadi coklat tua atau hitam yang dilihat dari dari kaca intip mesin roasting.

Menjelang kopi itu matang secara fisik, akan terdengan bunyi biji pecah (crack) dalam proses peroastingan dikenal pecah biji pertama (1 ${ }^{\text {st }}$ crack) dan pecah biji kedua (2 ${ }^{\text {nd }}$ crack). Pecah pertama menunjukkan biji kopi sudah mulai matang, pecah biji kedua maka biji kopi sudah siap untuk dikeluarkan dari tabung mesin roasting. Keluar dari tabung roasting harus secepatnya didinginkan agar biji kopi tidak bertambah matang akibat panas yang dibawanya.

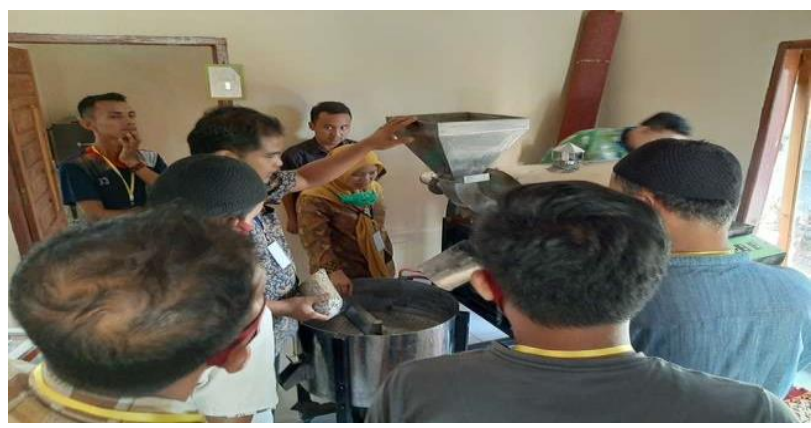

Gambar 6. Proses roasting kopi selama lebih kurang 20 menit

Proses pendinginan erlangsung secara cepat pada sistem pendinginan pada mesin roasting. Sistem pendinginan ini dilengkapi dengan blower untuk menghispa panas yang masih tersisa pada biji kopi.

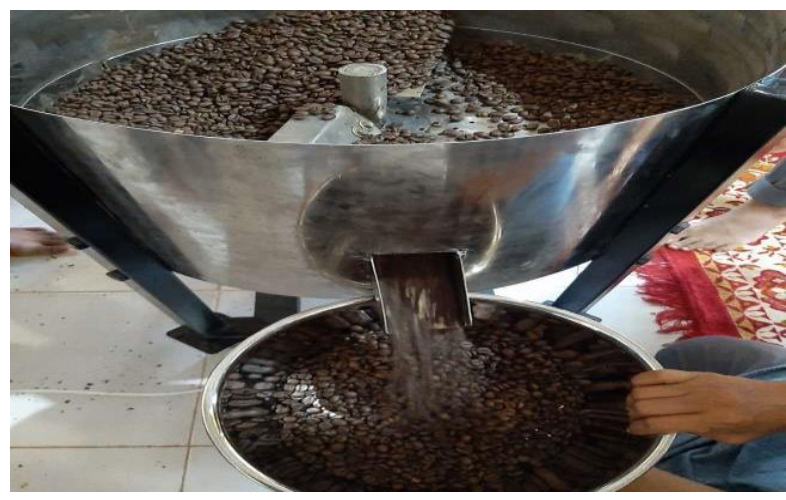

Gambar 7. Proses pendinginan cepat kopi setelah diroasting 


\section{Suluah Bendang: Jurnal Ilmiah Pengabdian Kepada Masyarakat}

Vol.20, No.3, 2020

Arwizet Karudin, Sri Rizki Putri Primandari, Zainal Abadi

Proses selanjutnya setelah didinginkan maka biji kopi hasil roastingan tersebut siap untuk di grinding atau digiling menjadi bubuk halus. Secara teknis sebaiknya biji hasil roasting didinginkan 2-3 hari terlebih dahulu, baru digrinding.

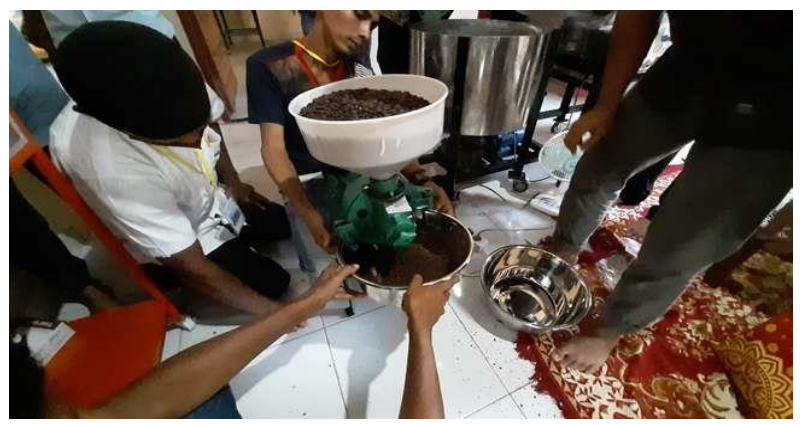

Gambar 8. Proses penggrindingan kopi menjadi bubuk kopi

Setelah digrinding/giling maka akan berbentuk bubuk halus yang siap untuk dikonsumsi aau dipacking supaya mudah dipasarkan ke masyarakat.

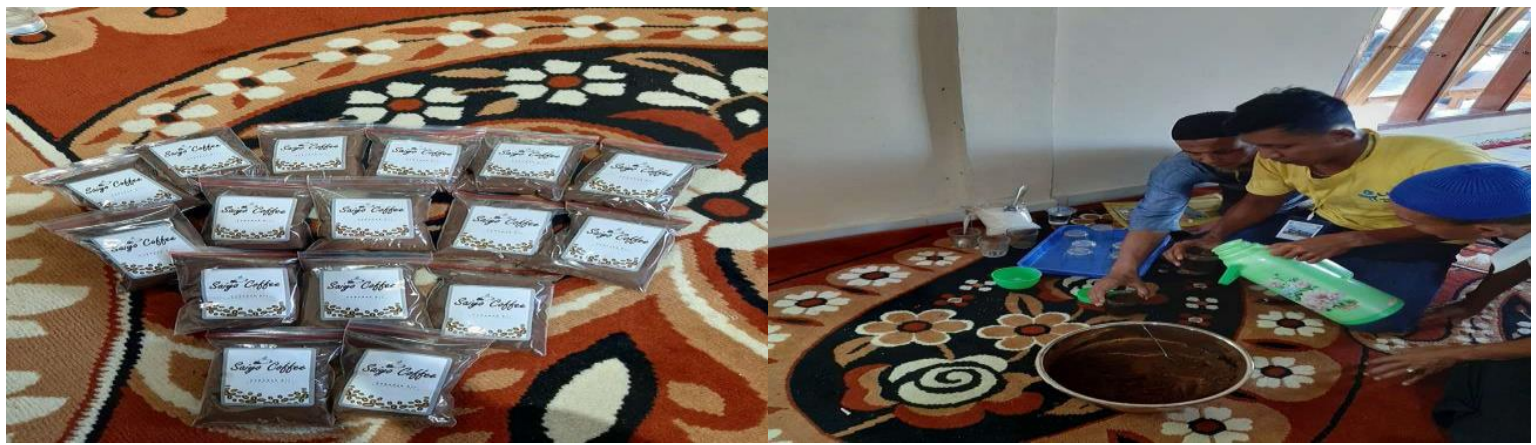

Gambar 9. Bubuk kopi siap untuk dikonsumsi dan dipacking supaya mudah dipasarkan

Pemberian Pengetahuan tentang Manajemen, Keuangan dan Pemasaran

Metode ceramah digunakan untuk memberikan pengetahuan tentang manajemen usaha khususnya usaha pembuatan bubuk kopi. Peserta juga diberikan pengetahuan tentang teknik pengelolaan keuangan dan pemasaran. Pengelolaan keuangan diajarkan bagaiman membuat pembukuan keuangan yang baik, sehingga cah flow keuangan perusahaan dapat tercatat dengan baik, sedangkan teknik pemasaran disarankan kepada mitra agar membuat plang nama, kartu nama dan promosi dengan media cetak dan media online.

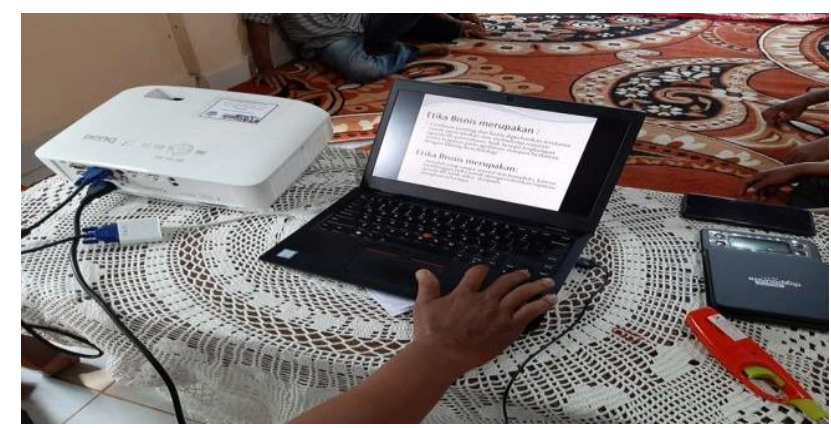

Gambar 10. Pelatihan manajemen usaha, keuangan dan pemasaran

Peningkatan Kemampuan Berwirausaha Pembuatan Bubuk Kopi Bagi Ikatan Pemuda..| 138 Available online: http://sulben.ppj.unp.ac.id 
Peningkatan Pengetahuan dan Keterampilan Peserta

Hasil pengukuran yang dilakukan oleh Program Kemitraan masyarakat (PKM) Pelatihan Peningkatan Kemampuan Berwirausaha Pembuatan Bubuk Kopi bagi Iakatan Pemuda Desa Cubadak Air dan Sikapak Barat Kelompok Masyarakat kepada peserta pelatihan dengan cara memberikan test kecil dan melalui proses pengamatan. Kepada setiap peserta diberikan nilai (score) tertentu sesuai dengan pengamatan pengambil data.

Dari gambar 11 dan 12 terdapat perbedaan yang cukup signifikan pengetahuan peserta secara teoritis tentang jenis kopi, teknis peroastingan kopi, grinding dan packing kopi serta maajemen usaha, keuangan dan pemasaran sebelum dan sesudah pelatihan.

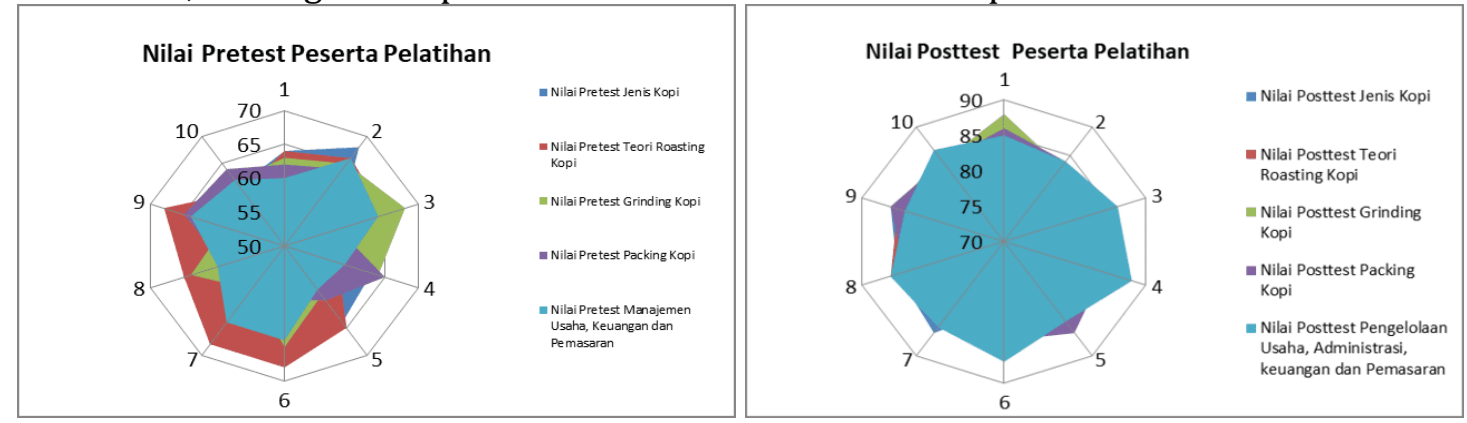

Gambar 11. Pelatihan manajemen usaha, keuangan dan pemasaran

Hasil pretest peserta sebelum pelatihan terkait dengan materi karakteristi dan jenis kopi, teknis roasting, grinding, packing dan manajemen usaha, keuangan dan pemasaran skor rataratanya adalah 63,0 dan setelah pelatihan skor rata-rata untuk materi di atas adalah 84,2. Dari hasil posttest tersebut dapat disimpulkan bahwa terjadi peningkatan yang signifikan pemahaman peserta setelah pelatihan. Dari hasil pengamatan diperoleh bahwa motivasi, kehadiran dan aktivtas peserta selama pelatihan dinilai baik, sedangkan dari sisi kemampuan mereka dalam melakukan proses peroastingan, grinding dan packing dinilai cukup baik.

\section{SIMPULAN}

Setelah dilaksanakan program kemitraan masyarakat daalam bentuk Pelatihan Peningkatan Kemampuan Berwirausaha Pembuatan Bubuk Kopi bagi Ikatan Pemuda di Desa Cubadak Air dan SIkapak Barat, maka dapat disimpulkan: 1) Peserta pelatihan mampu menyerap pengetahuan tentang kopi, teknis roasting, grinding dan packing yag diberikan oleh instruktur, 2) Hampir semua peserta telah mampu melakukan pekerjaan pembuatan bubuk kopi menggunakan mesin roasting, grinding dan packing, 3) Bubuk kopi dengan berbagai variasi rasa yang dihasil oleh peserta selama pelatihan sudah layak konsumsi dan layak jual, 4) Biji kopi yang tidak baik akan menghasil bubuk kopi yang juga kurang baik.

\section{REFERENSI}

F. Ihsan \& Q. Pramukanto. (2017). Perencanaan Lanskap Kota Pariaman Provinsi Sumatera Barat Berbasis Mitigasi Tsunami. Jurnal Lanskap Indonesia, 9 (1), 1-12.

Tim Penyusun. (2017). Propil Desa Cubadak Air Kota Pariaman. Pareko Ekspress.

F. P. M. Heru. (2014). Proses Pelaksanaan Penangkapan Tersangka Tindak Pidana Narkotika Pada Tingkat Penyidikan (Studi Kasus Polres Kota Pariaman). Thesis, Universitas Andalas.

A. Putri, R. Hariance, \& N. Nofialdi. (2017). Pengaruh Orientasi Kewirausahaan Terhadap Kinerja

Produk Pada Agroindustri Kopi di Kota Bukittinggi. Jurnal Lahan Suboptimal: Journal of

Suboptimal Lands, 6 (1),1-6. 
Suluah Bendang: Jurnal Ilmiah Pengabdian Kepada Masyarakat

Vol.20, No.3, 2020

Arwizet Karudin, Sri Rizki Putri Primandari, Zainal Abadi

A. A. Mita, A. Imron, \& S. T. Sarena. (2017). Rancang Bangun Alat Penyangrai (Roaster) Kopi dan Penggiling (Grinder) Kopi Otomatis Berbasis Mikrokontroler. Proceedings Conference on Design Manufacture Engineering and its Application, vol. 1, 155-160.

P. D. PEMASAR. (2008). Manajemen Pemasaran.

A. Supriatna \& B. Dradjat. (2012). Pola Kemitraan dalam peningkatan efisiensi pemasaran kopi rakyat. Litbang Pertanian.

I. Taruna. (2011). Rancang Bangun Mesin Penyangrai Kopi Tipe Rotari.

A. Afriliana. (2018). Teknologi Pengolahan Kopi Terkini. Deepublish. 